\title{
ДІТИ 3 ОСОБЛИВИМИ ПОТРЕБАМИ В УМОВАХ КРИЗОВИХ ВИКЛИКІВ: НАВЧАННЯ І СУПРОВІД
}

Наукова доповідь на вебконферениії «Учені НАПН України - українським

учителям», 25 серпня 2021 р., м. Київ, Україна

https://doi.org/10.37472/2707-305X-2021-3-2-17-11

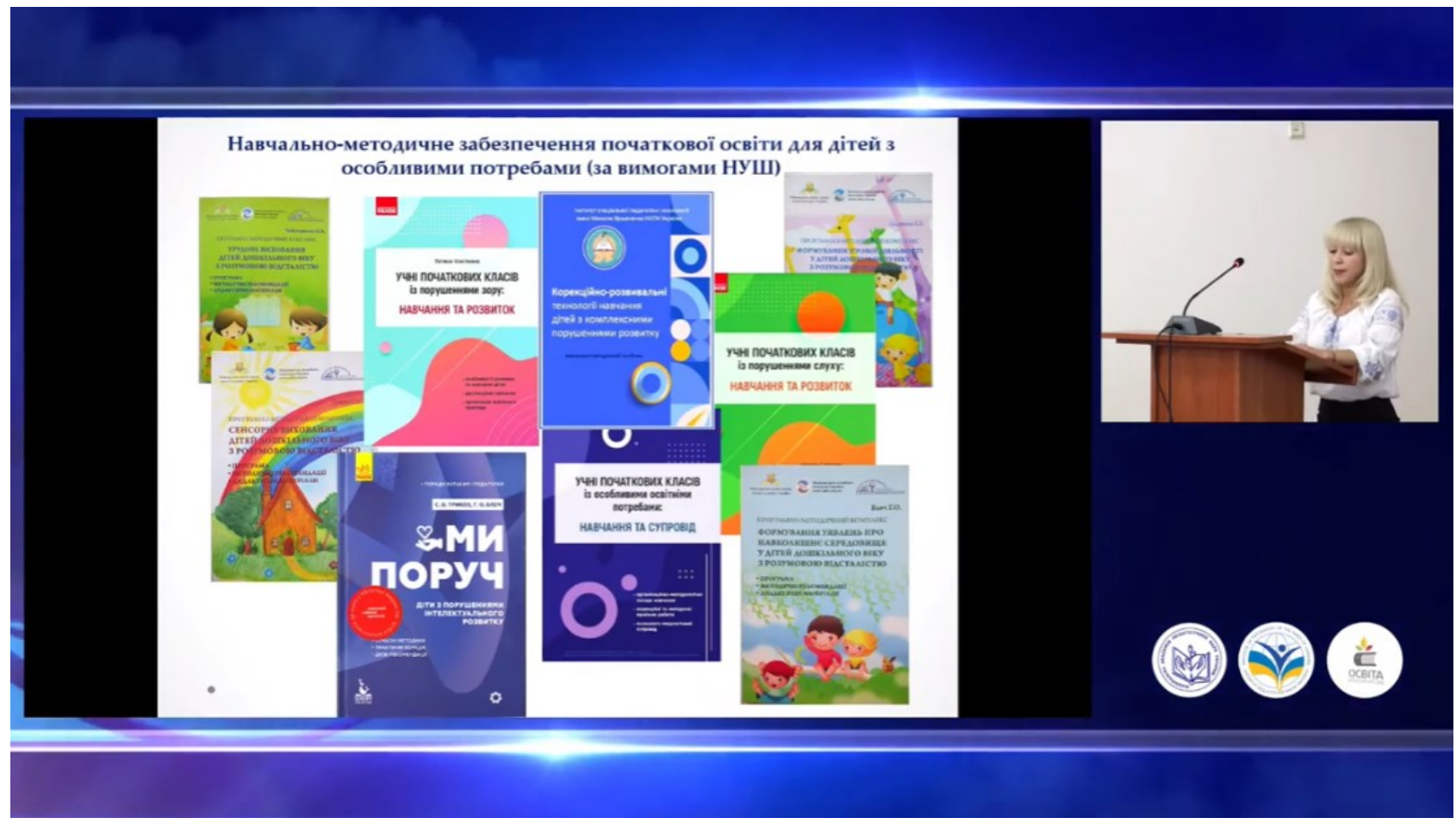

ПРОХОРЕНКО Леся Іванівна

доктор психологічних наук, професор,

директор Інституту спеціальної педагогіки

і психології імені Миколи Ярмаченка

Національної академії педагогічних

наук України, м. Київ, Україна

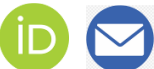

\section{ОРЛОВ Олег Вікторович}

кандидат психологічних наук, заступник директора з науково-експериментальної роботи Інституту спеціальної педагогіки і психології імені Миколи Ярмаченка Начіональної академії педагогічних наук України, м. Київ, Україна

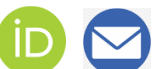

Анотація. Представлено ключові положення наукової доповіді на вебконференції «НАПн України українським учителям» в рамках Плану заходів НАПн України з відзначення 30-ї річниці Незалежності України. Автори стисло окреслили загальні аспекти навчання і психолого-педагогічного супроводу дітей з особливими потребами та їхніх родин, які перебувають в умовах кризових викликів, спричинених поширенням коронавірусу SARS-CoV-2. Зазначено, що кризові процеси, які виникли з введенням карантинного режиму в країні через пандемію SARS-CoV-2, призвели до виникнення труднощів та проблем, пов'язаних з наданням психологічної допомоги родинам дітей з особливими потребами, які перебувають в умовах ізоляції. Насамперед че стосується забезпечення доступу учнів, зокрема осіб з особливими потребами, до дистаниійної освіти. Адже саме ці діти, в умовах кризових викликів, не отримують необхідних знань, умінь $і$ навичок, потрібних для повноцінного життя у сочіумі.

Наголошено, що найпоширенішою методикою навчання дітей з особливими потребами, що передбачає застосування інформаційних технологій, є дистанційне навчання, позаяк иі діти винятково потребують розвитку своїх здібностей і досягнення успіхів у школі і в подальшому житті. 
Охарактеризовано основні принципи дистанційного навчання дітей з особливими освітніми потребами (інтерактивності, диференціації, індивідуального підходу, пластичності). Зазначено, що дистанційне навчання базується й на принципі гнучкості місця, часу, темпу та траєкторії навчання, тому в навчанні необхідно використовувати ці переваги для формування самостійної відповідальності учнів за власну навчальну траєкторію, нарощувати автономність у процесі навчання. Акцентовано на необхідності оптимізації навчання, яке проходить у звичному режимі (адаптація тематичного планування, вилучення несуттєвих тем, комбінування матеріалу кількох тем в одну, перегляд очікуваних результатів навчання, їх коригування тощо) до умов дистанційного навчання.

З урахуванням основних тенденцій щодо змін у системі освіти дітей з особливими освітніми потребами окреслено напрями діяльності, які потребують підвищеної уваги. Провідними серед них $\epsilon$ науковометодичний супровід освіти осіб з особливими потребами, корекційно-розвивальний та психологопедагогічний супровід таких осіб у прочесі навчання, соціалізації, життєдіяльності.

До основних стратегій розвитку дистанційної освіти віднесено орієнтацію на забезпечення максимально можливої диференціації навчання, його особистісно-орієнтованого і компетентнісного підходів.

Охарактеризовано основні здобутки дистанційної освіти та окреслено коло проблемних питань психолого-педагогічного та корекційно-розвивального супроводів дітей з особливими потребами, що їх необхідно вирішити якнайшвидше.

Ключові слова: освіта; дистанційне навчання; діти з особливими потребами; корекційно-розвивальна робота; психолого-педагогічний супровід.

Світова освітянська спільнота зіштовхнулася 3 глобальним викликом, зумовленим пандемією, спричиненою поширенням коронавірусу SARSCoV-2, і нові вимоги до забезпечення освітнього процесу стали викликом для вітчизняної системи освіти.

Пандемія вплинула на звичні режими життя людей, у тому числі осіб з особливими потребами та їхніх родин, загострилася низка соціальноекономічних питань, серед яких: рівність доступу до навчання (різний рівень забезпеченості родин засобами для дистанційного навчання); надання освітніх послуг дітям з особливими освітніми потребами (більшість цих дітей мають значні труднощі щодо отримання освітніх послуг дистанційно); проблеми спільного перебування в сім'ї 24/7 (передусім це стосується родин, які мають дітей дошкільного та молодшого шкільного віку); інші соціально-економічні проблеми, зумовлені пандемією.

Утім, негативний вплив пандемії найбільше відбився на родинах, які виховують дітей з особливими потребами, і тих, які перебувають у складних соціально-економічних умовах. Соціальна ізоляція, викликана пандемією, для таких дітей фактично перервала освітній процес, позбавила їх доступу до соціального спілкування, загострила проблеми відносин у родині, посилила економічні труднощі для їхніх батьків, які втратили роботу.

Родини дітей з особливими потребами зазначають численні зміни, які відбулися у їхньому житті, зокрема:

- зміни в режимі дня (дітям тяжко сприймати новий режим, тому що вони адаптовані до постійного і сталого режиму дня);
- перехід до нової форми навчання (для багатьох дітей з особливими освітніми потребами дистанційна форма навчання $є$ новою, незнайомою і незрозумілою. Вони не розуміють, що саме потрібно робити на онлайн-уроках: сидіти і слухати вчителя чи дивитися в екран монітору);

- неможливість виходу на вулицю/ігровий майданчик (через те, що не можна виходити на вулицю, погратися на ігровому майданчику, відвідувати басейн, а часто це було заспокоєнням для дитини з особливими освітніми потребами, у неї змінюється стиль поведінки);

- родина перебуває в одному просторі 24/7, що негативно відбивається на стратегіях поведінки дитини;

- перебування в емоційно-напруженій ситуації (в умовах вимушеної ізоляції дитина перебуває в емоційно-напруженій ситуації навіть удома, тому що дорослі хвилюються, бояться змін, які відбуваються в житті дитини в період карантину, бояться захворіти та ін. А діти з особливими потребами дуже чітко відслідковують емоції та почуття від дорослих і, звісно, теж відчувають острах, тривогу, панікують і емоційно вибухають);

- буденність та однаковість днів;

- нерозуміння причин, чому потрібно залишатися вдома (здебільшого діти з особливими потребами не розуміють причин, чому потрібно залишатися вдома, чому не можна йти в школу, чому не можна зустрітися з друзями, побачити однолітків та ін.).

В Україні близько 165 тис. дітей з особливими освітніми потребами, і більшість з цих дітей мають різні перешкоди та проблеми, які почалися із впровадженням дистанційного навчання, синхро- 
нізацією освітнього процесу, побудовою дистанційного освітнього середовища та ін.

У цьому контексті чимало досліджень і практичних напрацювань присвячено інтегруванню дітей та молоді з особливими потребами до загальноосвітнього простору. Насамперед ідеться про особистісну орієнтацію освіти; створення рівних можливостей для дітей та молоді у здобутті якісної освіти; забезпечення варіативності здобуття базової або повної загальної середньої освіти відповідно до здібностей та індивідуальних можливостей (В. Засенко, Є. Клопота, Т. Костенко, Л. Прохоренко, О. Романенко, Г. Соколова, К. Тороп, А. Шевцов, Н. Ярмола та ін.). Для таких осіб розроблено моделі дистанційного навчання в умовах карантину, які дають змогу працювати вдома з усім класом під керівництвом учителя, який може стати спікером для батьків у допомозі оволодіння методами засвоєння навчальних знань.

У результатах досліджень зазначено, що дистанційне навчання має низку характеристик, які відрізняють його від інших способів отримання традиційної освіти й підкреслюють інноваційність та актуальність навчального процесу, в якому інтерактивна взаємодія вчителя й учня має регулярний, а не епізодичний характер. Окреслено проблемні моменти в організації дистанційного навчання в системі освіти, а також визначено низку перешкод у забезпеченні якості освіти та ефективного доступу до навчання кожної дитини з особливими потребами в умовах дистанційного режиму.

Перевагою дистанційного навчання $€$ постійний доступ кожного учня до теоретичного матеріалу у зручний для нього час та у привабливому індивідуальному темпі. Утім, використання дистанційного навчання можливе лише за наявності у кожної дитини доступу до персонального комп'ютера або інших девайсів та високоякісного інтернет-зв'язку.

До недоліків дистанційної форми навчання віднесено:

- відсутність очного спілкування учителя й учня (діти з особливими потребами не можуть здійснювати самостійну навчальну діяльність, а оскільки немає безпосередньої можливості здійснювати контроль за діями дітей з боку вчителя, це призводить до підвищення рівня негативних оцінок, зниження засвоєння матеріалу та ін.);

- неможливість забезпечити належну якість навчання за допомогою дистанційних технологій через відсутність необхідної технічної оснащеності;
- неможливість забезпечити самостійну роботу, особливо учнів молодшого шкільного віку (з одного боку, діти, що не мають достатнього досвіду самостійної роботи та вольової саморегуляції звичка до групового навчання у дитячих закладах, а з іншого - недостатнє організаційне та методичне забезпечення для самостійної роботи дітей);

- невміння здійснювати комунікацію на відстані як у дітей, так і в педагогів, та виникнення у зв' язку з цим комунікативного бар'єра і відсутності психологічного комфорту учасників дистанційного навчання.

Підсумовуючи напрацювання вчених і отриманий практичний досвід, можна стверджувати, що впровадження дистанційного навчання дітей 3 особливими освітніми потребами створює низку труднощів як організаційного, так і методичного характеру, обумовлених як модально-неспецифічними закономірностями розвитку цих дітей (зниження обсягу та швидкості сприймання й переробки інформації; порушення розумової та фізичної працездатності, виникнення компенсаторних і псевдокомпенсаторних пристосувань; своєрідністю взаємодії з іншими людьми), так і модально-специфічними закономірностями розвитку дітей певної нозологічної групи й індивідуальними потребами та можливостями конкретної дитини.

Організовуючи дистанційне навчання дітей $з$ особливими освітніми потребами, важливо пам'ятати, що вся освітня діяльність має спиратися на сильні сторони дитини, відповідно до її можливостей і потреб, з урахуванням особливостей нового «домашнього освітнього» середовища. Ключовою залишається проблема збереження здоров'я дитини, суворе дотримання охоронно-педагогічного режиму.

Власне, від самого початку навчального року, від його організації, від стану та якості навчальнометодичного забезпечення, від форм і технологій подачі матеріалу учням залежить не лише якість їхніх знань, а й наявність і кількість прогалин у знаннях, які на відміну від фінансових чи моральних втрат, залишаються на все життя. I найбільше це стосується дітей з особливими освітніми потребами, з якими зазвичай у спеціальних чи інклюзивних закладах освіти проводиться, окрім навчання, системний психолого-педагогічний супровід і, що важливо, корекційно-розвивальна робота.

Будь-яка форма навчання, зокрема й дистанційна, для осіб з особливими освітніми потребами 


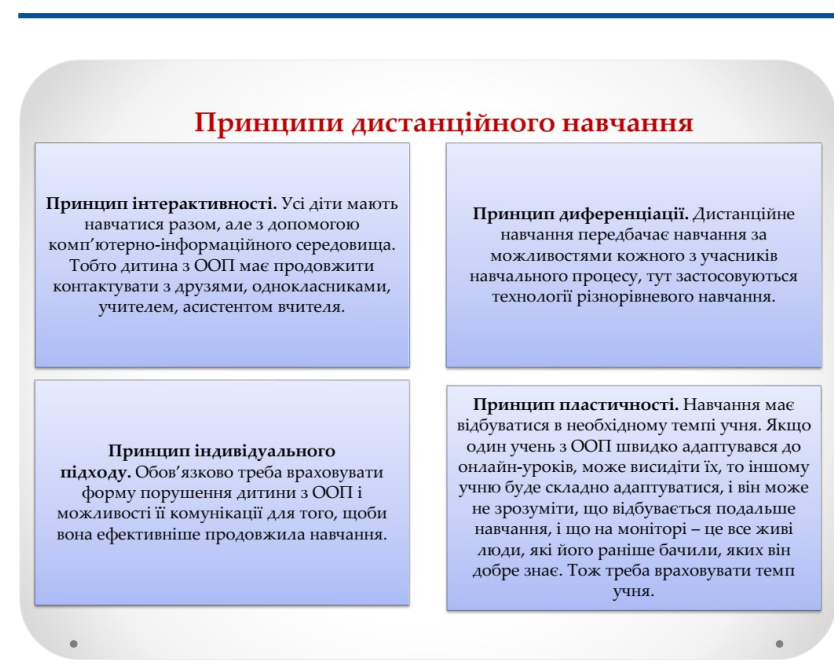

здійснюється з урахуванням індивідуальної програми розвитку. Тобто під час проведення уроків, корекційно-розвивальних занять необхідно враховувати рішення команди психолого-педагогічного супроводу щодо індивідуалізації навчання дитини з ООП.

Освітній процес під час дистанційного навчання осіб з оОП забезпечується за участі вчителя, але гарантом зворотного зв'язку з дитиною $є$ батьки, які сприяють реалізації індивідуальної освітньої траєкторії дитини. Втім, у процесі дистанційного навчання як діти, так і вчителі, стикаються 3 низкою перешкод: індивідуальні особливості розвитку дитини, нові умови навчання, невміння використовувати комп'ютерні технології та інтернетресурси й ін. Під час дистанційного засвоєння знань спостерігається зниження ступеня сприйняття та складність виокремлення необхідної інформації дітьми з ООП, погіршення стану здоров'я через постійний контакт з IKT, зниження ролі вчителя в освітньому процесі.

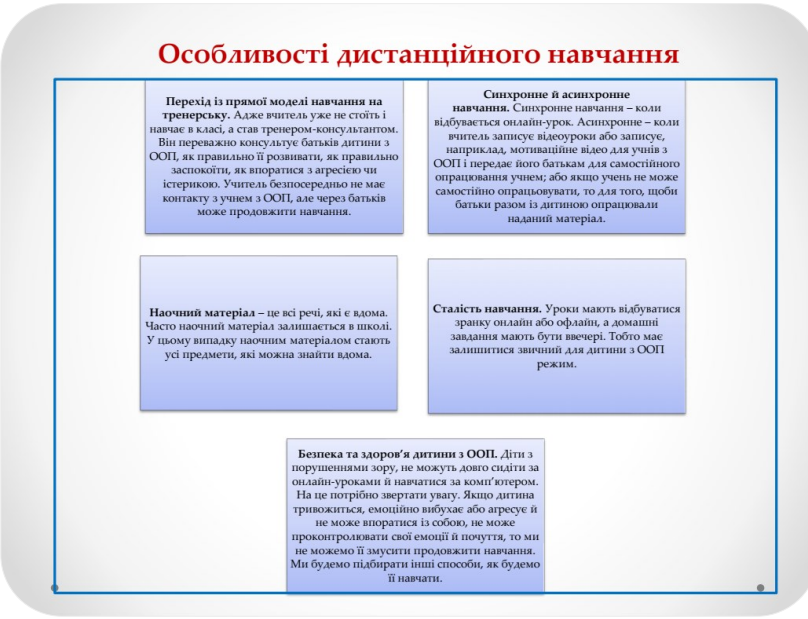

Все це обумовлює:

- формування адаптивного дистанційно-освітнього середовища для вчителів і дітей;
- створення єдиного дистанційного освітнього стандарту: підручників нового покоління, методичних рекомендацій, навчальних посібників, а також різних комплексів і програм;

- збільшення кількості контактної роботи 3 педагогом для опрацювання невирішених питань через синхронні очні або онлайн-занятт, змішане навчання;

- використання інновацій у галузі дистанційної освіти;

- створення сприятливої атмосфери для навчання.

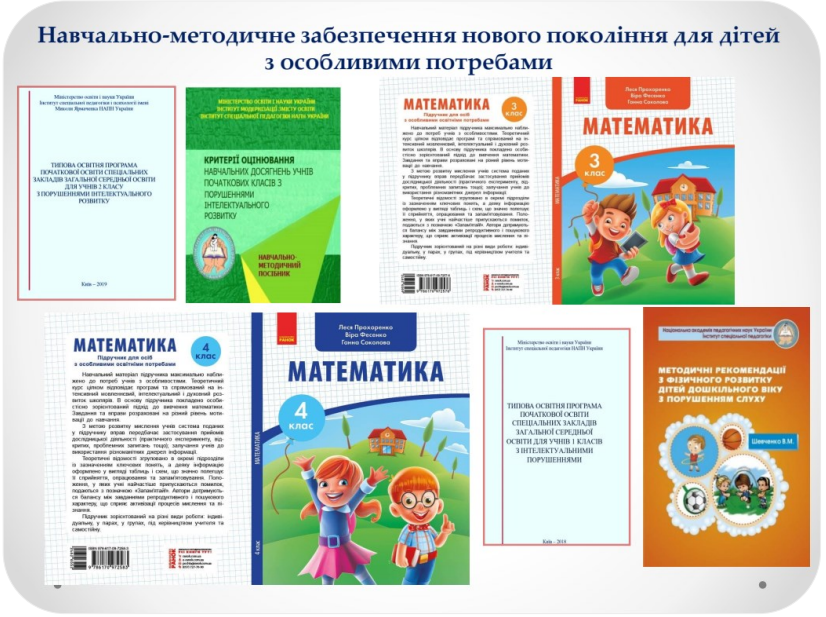

Водночас нагальним питанням є розроблення комплексної психолого-педагогічної підтримки родин дітей з особливими потребами у кризових ситуаціях та дистанційної моделі психологічної, педагогічної та методичної роботи, що передбачатимуть застосування не лише консультативних, а й психокорекційних та психотерапевтичних методів і процедур як у процесі дистанційного навчання, так і під час побутового спілкування $з$ родиною.

В умовах довготривалого карантину основним завданням діяльності команди психологопедагогічного супроводу дітей з особливими освітніми потребами є створення оптимальних умов для здобуття освіти дітьми з урахуванням їхніх індивідуальних потреб та можливостей із застосуванням технологій корекційно-розвивального навчання в домашньому здоров'язбережувальному освітньому середовищі.

У ситуації соціальної ізоляції вкрай багато залежить від взаємоприйняття, взаємоповаги, взаєморозуміння, взаємодії та взаємопідтримки вчителя, асистента вчителя і батьків «особливої» дитини, а також відповідального ставлення й усвідомлення того, що вся ця діяльність - задля дитини. 
У процесі дистанційного навчання батьки мають бути партнерами для вчителів. Тобто роботу психолого-педагогічного супроводу необхідно зосередити насамперед на батьках, і вже потім на їхніх дітях, тому що саме батьки стають каналом комунікації між учителем і учнем, організовують самостійне навчання дитини, налаштовують дитину на успіх, всіляко допомагають їй та підтримують

Потрібно зазначити, що для успішної реалізації супроводу батьків в умовах дистанційного навчання дитини надзвичайно важливим є: залучення їх до освітнього процесу, консультування щодо особливостей виконання запропонованих завдань, урахування індивідуальної працездатності дитини відповідно до стану ії здоров'я, моніторинг динаміки втомлюваності, дотримання охоронного режиму, позитивні емоції педагогів та батьків тощо.

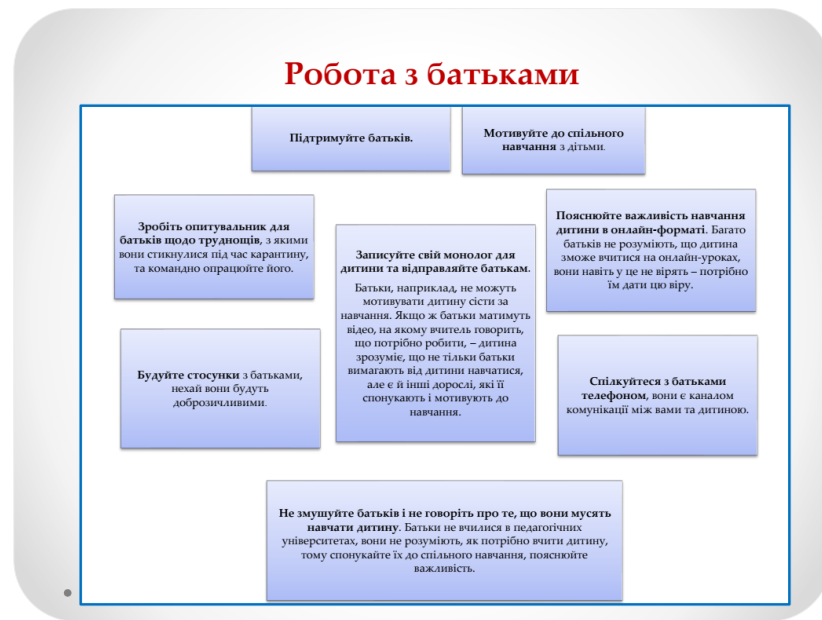

Принагідно зауважимо, що дистанційне навчання передбачає різноманітні види підтримки. У сумісній взаємодії з батьками вчитель або асистент вчителя визначають - які завдання дитина може зробити самостійно, а що дитина може зробити з підтримкою дорослого, разом із дорослим; з чим дитина не може впоратися навіть із підтримкою. Важливо ще на початку дистанційного навчання з'ясувати труднощі, з якими стикається дитина, чого вона не може зробити, а також сильні сторони - що вона може зробити (наприклад, якщо учень не може сидіти біля комп'ютера, але може стоячи займатися 15 хвилин, йому можна дати змогу виконувати завдання стоячи). Після такого оцінювання і вчитель, і батьки будуть знати, які завдання дитині потрібно давати на онлайн-уроках, а які не потрібно давати у жодному разі, тому що дитина з ними впоратися не зможе.
Проведено дистанційні заходи (онлайн-вебінари, відео-консультації, онлайн-тренінги та ін.)

-Про6лемна поведінка Аітей з особливими потре6ами: виправлення та корекція) - Режим Аоступу: hौlp://ispukr.orq.ua/?p=5750\#.XrPE0xQzbX4 - Небажана повеАінка у Аітей з розмадами аутистичного спектра та шляхи iї усунення" - Режим Аоступу: http://ispukr.orq.va/?p=5502\#.XrPLnXQzbX4 -Психомого-пеАагогічний супровіА та реабімітащія Аітей з особливими освітніми потребами) - Режим Аоступу:

ocвін hifp://ispukr.orq.va/?p=589\%.X007k4ozbX4 Вітчизняні технологї організаци АогопеАичноїАОПомоги АІтям 3 особливими мовленневими потребами Режим Аоступу: hltp://ispukr.orq.ua/?p=5338\#.XrPMxhQzbX

-Шляхи оптимізації психічного стану Аітей з ООП в умовах спеціальної школи) - Режим Аоступу: http://ispukr.orq.va/?p=5247\#.XrPOmBQzbX4 •ОнАайн навчання учнів з порушеннями слуху: рекоменАації шкільним команАам супровоАу -Режим Аоступу: hltp://ispukr.orq.ua/?p=5766\#.X00$340 z b \times 4$

-Наука та практика: пращюемо разом заАмя Аітей 3 особливими потребами - hllp://ispukr.orq.va/?p=5778\#.XOPAjoozbX4

-Міжнароана науково-практична офАайн-он^айн конференція "Практична психологія в інклюзивному сереАовищі- 2020». - Режим AOступу: hltp://ispukr.orq.ua/?p=5317\#.XrPNiRQzbX4

Варто також зупинитися на основних видах підтримки в умовах дистанційного навчання:

- фізична підтримка - повна чи часткова (наприклад, якщо дитина може самостійно малювати, то підтримка від дорослого не потрібна. Втім, якщо у дитини порушення опорно-рухового апарату, і взяти ручку або фломастер вона сама не може, їй потрібна допомога - це буде часткова допомога, бо малювати вона може. Повна підтримка - якщо дитина з порушенням опорнорухового апарату не рухає руками. Тоді батьки мають сідати поруч, вкладати фломастер їй у руку й починати малювати разом із нею);

- вербальна підтримка - повна чи часткова (похвала від батьків, інших дорослих; батьки сидять на онлайн-уроці разом із дитиною і повністю дублюють завдання вчителя для дитини, щоб вона могла його виконати; батьки ставлять навідні запитання, пояснюють умову, щоб дитина зрозуміла завдання);

- підказки - жести, рухи тіла, вказівки, використання міміки;

- візуальний стимул - малюнки, фотографії, піктограми, символи, письмові слова тощо;

- моделювання - демонстрація виконання завдання (дорослий моделює те, що озвучує вчитель, - або малює, або представляє у вигляді схеми);

- маніпуляція символами - розташування об'єктів у визначеному порядку (можна маніпулювати, розташовуючи в порядку, що буде зараз, що буде потім, а що буде після).

У ході планування навантаження кожного заняття потрібно мати на увазі, що самостійне опрацювання матеріалу учнями з особливими потребами триває довше, аніж виклад цього матеріалу вчителем, тому варто скоротити, наскільки це можливо, теоретичний обсяг матеріалу. Тобто оптимізувати тематичне планування, вилу- 
Приклади комунікативних карток

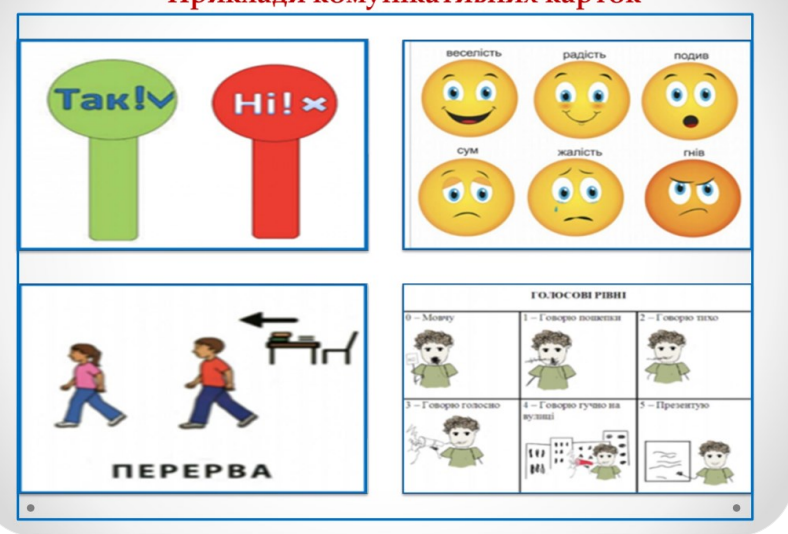

чити несуттєві фрагменти, комбінувати матеріал кількох тем в одну. Водночас доцільно переглянути очікувані результати навчання і встановити дещо нижчий їх рівень або цілком їх скоригувати, якщо в умовах дистанційного навчання їх досягнення $є$ надто складним.

Навантаження дитини з особливими потребами визначають індивідуально, з огляду на можливості кожної дитини. Його підбирає команда психолого-педагогічного супроводу. Навантаження складають на тиждень, після чого проводять аналіз, що вдалося зробити, від чого дитина сильно втомлювалася, що потрібно змінити.

Таким чином, психолого-педагогічний супровід дитини з особливими потребами в умовах вимушеної соціальної ізоляції спрямований на створення соціально-психологічних умов для успішного навчання, виховання та психічного розвитку на всіх етапах навчання дитини та життєдіяльності:

nо-перше, це систематичне відстеження психолого-педагогічного статусу дитини і динаміки їі психічного розвитку в процесі виховання та навчання;

по-друге, створення необхідних умов для розвитку особистості дитини та її успішного навчання в «домашніх» умовах;

no-mpem $\epsilon$, розроблення та використання спеціальних методик, програм та прийомів для надання допомоги дітям, які мають виражені проблеми у розвитку та поведінці і перебувають у кризових умовах.

Важливе значення для забезпечення ефективного навчання у дистанційному режимі дітей з особливими освітніми потребами відіграє корекційно-розвивальний супровід дитини в освітньому процесі. Основним завданням такого супроводу $є$ встановлення зв'язків, які впливають на успішність та результативність навчально-виховного процесу. Плануючи свої виховні дії, батьки мають творчо підходити до процесу навчання своєї дитини, забезпечувати їі емоційний комфорт та створювати умови для особистісного та інтелектуального розвитку. Психолог і вчитель моделюють процес впливу відповідно до потреб та можливостей дітей, відслідковують динаміку розвитку їх пізнавальної діяльності, особливостей особистісного розвитку, комунікативної активності, систематизують та інтегрують різноманітні підходи до дитини в процесі виховання та навчання, розробляють власну тактику роботи тощо.

Зокрема, в умовах вимушеної соціальної ізоляції корекційно-розвивальний вплив $є$ основою педагогічної технології індивідуального підходу до дитини з особливими потребами. Він містить проведення в онлайн-форматі (індивідуально або колективно) консультацій з батьками щодо організації і проведення дистанційних занять (наприклад, якщо немає технічного забезпечення, корекційний педагог чи логопед консультує батьків, що вони можуть зробити на цьому рівні); заняття для розвитку життєвих компетентностей та соціально-побутового орієнтування дитини в умовах домашнього середовища (навчитися мити посуд, приготувати сніданок, прибрати на столі, застелити ліжко) тощо.

Безумовно, означені питання та багато інших $\epsilon$ чи стануть у центрі уваги дослідників, управлінців і практиків. Утім, як на нашу думку, існують певні проблеми навчання і супроводу дітей з особливими потребами в умовах кризових викликів, які потребують нагального вирішення, а саме:

- неготовність інформаційно-освітнього середовища закладів освіти до підтримки цілісного процесу електронного навчання

- мала кількість учителів, які володіють сучасними педагогічними та інформаційними технологіями, психологічно готові до роботи із студентами у новому навчально-пізнавальному мережевому середовищі;

- відсутність методик викладання в електронному середовищі;

- недостатнє забезпечення навчально-методичними матеріалами навчання та виховання дитини в умовах вимушеної соціальної ізоляції;

- інфраструктура інформаційного забезпечення дитини в мережах та ін.

Методичною проблемою $€$ відсутність методик створення і використання дистанційних курсів у навчальному процесі на основі сучасних педагогічних, інформаційних і комунікаційних тех- 


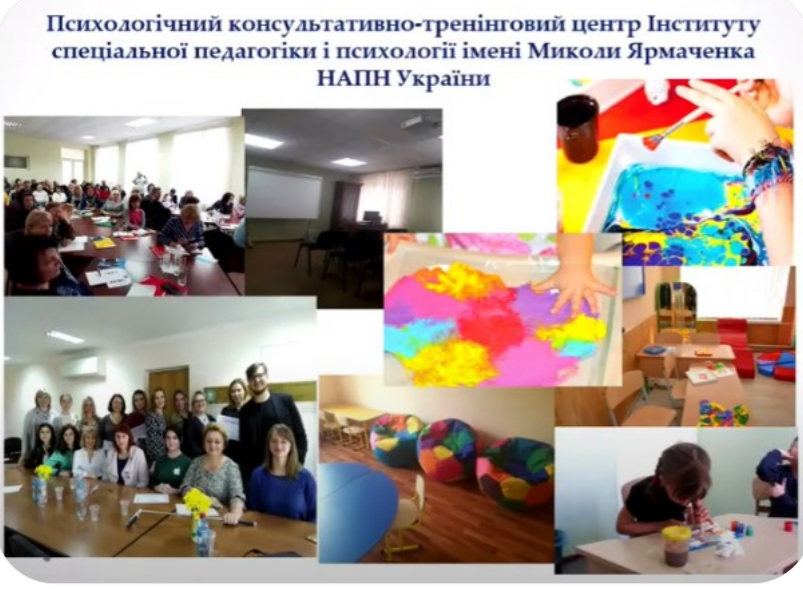

нологій. Це завдання мають вирішувати спільно освітяни, науковці й розробники дистанційного навчання в контексті створення сучасних інноваційних технологій, зокрема електронного контенту.

I наостанок важливо додати, що після аналізу ефективності технологій, використаних під час дистанційного навчання, практик психологопедагогічного супроводу дітей з особливими потребами і їхніх родин, варто було $б$ розширити можливі технологічні рішення для забезпечення безперервного навчального процесу, організувати підвищення кваліфікації для вчителів, запропонувати ознайомчі курси чи окремі заняття для учнів та батьків.

Хотілося б, щоб досвід, набутий за умов екстреного переходу до умов дистанційного навчання, був використаний не лише для розвитку цифрових компетентностей учнів та вчителів, але й для рефлексії щодо особливостей розвитку дитини з особливими потребами в умовах кризових викликів, що є важливим елементом у забезпеченні індивідуального розвитку дитини, її успішної взаємодії у мікросоціумі та у подальшій інтеграції у суспільство.

\section{СПИСОК ВИКОРИСТАНИХ ДЖЕРЕЛ}

Богачков, Ю.М., Биков, В.Ю., Пінчук, О.П., Манако, А.Ф., Вольневич, О.І., Царенко, В.О., Ухань, П.С., \& Мушка, І.В. (2012). Організація середовища дистанційного навчання в середніх загальноосвітніх навчальних закладах : посібник (Ю.М. Богачков, наук. ред.). Київ: Педагогічна думка. https:// lib.iitta.gov.ua/626/

Дичківська, І.М. (2004). Інноваційні педагогічні технології : навчальний посібник. Київ: Академвидав. https://bit.ly/3EOKATA

Інститут педагогіки НАПН України. (2021, 25 серпня). Учені НАПН України - українським учителям. https://undip.org.ua/announce/ucheni-napn-ukrainyukrainskym-uchyteliam/

Кононенко, О.І., Прохоренко, Л.І., \& Соколова, Г.Б. (2019). Психологічний супровід родин, які виховують дітей з особливими потребами: контент-аналіз проблеми. In О.В. Царькова (заг. ред.), Концептуалізація системи сімейно-орієнтованого психологопедагогічного супроводу родини, яка виховує дитину з особливими потребами : колективна монографія (с. 10-22). Мелітополь: Люкс. https://cutt.ly/ dRbeyXg

Прохоренко, Л.І. (2019). Науково-психологічний супровід в освіті дітей з особливими потребами. Вісник Національної академії педагогічних наук України, 1(1). https://doi.org/10.37472/2707-305X-2019-1-1-1-5

Lytvynenko, O., Zlatova, L., Zasenko, V., Prokhorenko, L., \& Lunov, V. (2020). Adaptive Potential of Young People as a Factor of Mental Health-Preserving. Journal of History Culture and Art Research, 9(3), 374-385. https://doi.org/10.7596/taksad.v9i3.2846

Orlov, O. (2020). Reforming Ukrainian Health Care and Education After the Revolution of 2014: An Analysis of Parliamentary Discourse and Policy Change. In The Research Initiative on Democratic Reforms in Ukraine (pp. 56-73). Edmonton: University of Alberta. https:// bit.ly/3ajOdJJ

Petryshyn, R., Lutsenko, I., \& Orlov O. (2020). The Impact of Geopolitical and Military Parameters on Inclusive Education Reform in Ukraine and Crimea. In The Research Initiative on Democratic Reforms in Ukraine (pp. 74-91). Edmonton: University of Alberta. https:// bit.ly/3ajOdJJ

\section{CHILDREN WITH SPECIAL NEEDS IN CRISIS SITUATIONS: TRAINING AND SUPPORT \\ Scientific report at the web conference "The NAES of Ukraine Researchers to Ukrainian Teachers", August 25, 2021, Kyiv, Ukraine}

Lesia Prokhorenko

DSc in Psychology, Professor, Director, Mykola Yarmachenko Institute of Special Pedagogy and Psychology of the National Academy of Educational Sciences of Ukraine, Kyiv, Ukraine

Oleh Orlov

PhD in Psychology, Deputy Director for Research and Experimental Work, Mykola Yarmachenko Institute of Special Pedagogy and Psychology of the National Academy of Educational Sciences of Ukraine, Kyiv, Ukraine

Abstract. The key points of the scientific report at the web conference "The NAES of Ukraine Researchers to Ukrainian Teachers" within the Action Plan of the National Academy of Educational Sciences of Ukraine to celebrate the 30th anniversary of Ukraine's Independence are presented. The authors briefly outline the general aspects of training, as well as psychological and pedagogical support for children with special needs and their families who are in crisis conditions caused by the spread of coronavirus SARS-CoV-2.

It is stated that the crisis processes that arose with the introduction of the quarantine regime in the country, caused by the effects of the SARS-COV-2 pandemic, confirm the emergence of urgent difficulties and problems associated with 
providing psychological assistance to families of children with special needs insulation. First of all, it concerns the provision of access to distance education, in particular for people with special needs. After all, these children, in the face of crisis challenges, do not receive the necessary knowledge, skills, and abilities necessary for a full life in society.

It is emphasized that the most common method of teaching children with special needs, which involves the use of ICT, is distance learning, as these children especially need to develop their abilities and achieve success in school and later in life.

The basic principles of distance learning of children with special educational needs (interactivity, differentiation, individual approach, plasticity) are described. It is noted that distance learning is based on the principle of the flexibility of place, time, pace, and trajectory of learning, so in learning it is necessary to use these advantages to form independent responsibility of students for their own learning trajectory, increase autonomy in learning. It is emphasized on the need to optimize the training, which takes place in the usual mode (adaptation of thematic planning, removal of irrelevant topics, combining the material of several topics into one, reviewing expected learning outcomes, adjusting them, etc.) to the conditions of distance learning.

Taking into account the main trends in the education of children with special educational needs, areas of activity that require special attention are outlined, the leading ones being scientific and methodological support of the education of persons with special needs, correctional and psychological support of such persons in the learning process, socialization, life.

The main strategies for the development of distance education include the focus on ensuring the maximum possible differentiation of learning, its personality-oriented and competency-based approaches.

The main achievements of distance education are described; the range of problematic issues, psychological and pedagogical, correctional and developmental support for children with special needs that need urgent solutions is outlined.

Keywords: education; distance learning; children with special needs; correctional and developmental work; psychological and pedagogical support.

Дата публікації: 30 вересня 2021 р. 